\title{
REVIEW
}

\section{A Study on the Reform and Innovation of English Teaching in Colleges and Universities under the New Media Environment}

\section{Yan Chen}

Enshi Polytechnic, Enshi, Hubei, 445000, China

\begin{tabular}{|c|c|}
\hline ARTICLE INFO & ABSTRACT \\
\hline Article history & In the development of modern society, many advanced technologies have \\
\hline Received: 18 July 2019 & been applied to the development of various industries, ${ }^{[3]}$ and the applica- \\
\hline Revised: 5 August 2019 & $\begin{array}{l}\text { tion of new media technology has made great changes in the work and } \\
\text { study of the people. In the new media environment }{ }^{[1]} \text { English teaching }\end{array}$ \\
\hline Accepted: 9 October 2019 & in colleges and universities has improved the traditional teaching mode, \\
\hline Published Online: 16 October 2019 & $\begin{array}{l}\text { made the teaching idea get some innovation, and introduced many inno- } \\
\text { vative teaching methods, which stimulated the students' enthusiasm for }\end{array}$ \\
\hline Keywords: & learning ${ }^{[1]}$. Based on this, this paper expounds the importance of ${ }^{[8]}$ the \\
\hline New media environment & reform and innovation of English teaching in colleges and universities \\
\hline College English teaching & glish teaching in colleges and universities ${ }^{[2]}$, and studies the optimization \\
\hline Reform & measures for the reform and innovation of English teaching in colleges \\
\hline Innovation & and universities under the new media environment. \\
\hline
\end{tabular}

\section{Introduction}

$\mathrm{U}$ nder the background of the new curriculum reform, the traditional college English teaching model can no longer meet the requirements of English teaching in the new period. ${ }^{[3]}$ In order to cultivate more excellent English talents, college English teachers should constantly optimize English teaching methods ${ }^{[7]}$. In the new media environment, the application of many advanced technologies provides support ${ }^{[1]}$ for the reform and innovation of English teaching in colleges and universities. Relevant personnel need to reasonably apply new media technology to stimulate college students' enthusiasm for learning ${ }^{[8]}$, enrich English teaching resources, and optimize and innovate the existing English teaching mod$\mathrm{el}^{[2]}$. Therefore ${ }^{[4]}$ in the new media environment, teachers need to pay attention to the reform and innovation of English teaching in colleges and universities ${ }^{[1]}$.

\section{English Teaching in Colleges and Universi- ties under the Environment of New Media}

New media refers to a kind of information communication mode developed in modern society, which effectively merges sound, image, text and video, and can complete the work of information dissemination without the limitation of time and place. In modern college English teaching, new media technology has been effectively applied and widely valued by many colleges and universities ${ }^{[7]}$, but the emergence of new media has brought great influence ${ }^{[1]}$ on college English teaching, mainly in the following aspects: first, ${ }^{[4]}$ new media has brought some impact and challenges to college English teaching, the traditional college English teaching

*Corresponding Author:

Yan Chen,

Enshi Polytechnic, No. 122 Xueyuan Road, Enshi, Hubei, 445000, China;

E-mail:1457164161@qq.com. 
model has the characteristics of uniqueness[, many teachers in the actual college English teaching In the process ${ }^{[1]}$, we often only pay attention to the content of textbooks and rely on textbooks, tapes and CD-ROMs to carry out practical teaching activities. Many college students are used to this teaching mode, but cannot effectively improve students' oral expression ability, English communicative competence and English use ability, and ${ }^{[3]}$ it is difficult to effectively improve students' comprehensive English use ability. Second, the new media provides a lot of convenience ${ }^{[1]}$ for the reform and innovation of English teaching methods in colleges and universities. In the new media environment, many advanced teaching technologies and the effective application of teaching resources provide a free learning platform for college students, broaden the channels for students to obtain learning materials and teaching resources, and promote the effective application of teaching resources. With the further development of information ${ }^{[1]}$ teaching in colleges and universities, college English is one of the main contents in the process of ${ }^{[1]}$ teaching in colleges and universities, which directly affects the all-round development of students $^{[3]}$.

\section{The Importance of English Teaching Re- form and Innovation in Colleges and Univer- sities under the New Media Environment}

\subsection{Create a Good English Teaching Environment}

In the new media environment ${ }^{[4]}$, the teacher should actively introduce advanced technology, explain the key content of English teaching in the Internet platform, so that the students can better understand the contents in the teaching materials through the contents of pictures and videos in the teaching, So as to improve the oral English expression ability and the overall level of the students. At the same time, in the new media environment, the students can feel the fun of English teaching; realize the unity of theory and practice and the expected goal of common development.

\subsection{Promote the Effective Implementation of Teaching Activities}

In order to innovate and reform the English teaching mode of colleges and universities in China, teachers should implement informatization teaching methods. Colleges and universities are an important stage of students from school to society. College English teaching is one of the main contents in the process of informatization reform. In the new media environment, the traditional teaching mode of college English teaching has been changed, so that problems such as low efficiency and fixed thinking in tradition- al teaching are optimized ${ }^{[4]}$. Therefore, in the preparation stage of English teaching ${ }^{[5]}$, college English teachers can apply Internet technology to understand the communication and cooperation between China and other countries, and transfer them to students in English. Besides, in the new media, in the physical environment, students have a high interest in English teaching model, which stimulates students' enthusiasm for learning English to a great extent, and then improves the quality of English teaching in colleges and universities ${ }^{[2]}$.

\section{The Present Situation of English Teaching in Colleges and Universities in China}

\subsection{The Form of English Teaching in Colleges and Universities Is Too Written ${ }^{[5]}$}

At present, in the course of college English teaching, the problem of theory is more than practice. Many ${ }^{[2]}$ teachers only pay attention to the content in the textbooks and pursue the written teaching method, which greatly strikes the students' learning enthusiasm, which is difficult to ${ }^{[1]}$ stimulate the subjective initiative of students, and the college English $^{[3]}$ teaching not only needs students to master the book knowledge, but also affects the content of more language application and practice ${ }^{[1]}$ to cultivate the students' language practice ability and improve ${ }^{[5]}$ the students' comprehensive level. In the course of modern college English teaching, teachers only ${ }^{[1]}$ pay attention to the cultivation of students' language grasp, reading, writing ability, and lack of comprehensive application language. Teachers generally believe that English learning is memorizing words and sentences every day, which greatly affects students' ability to use English comprehensively. Especially ${ }^{[6]}$ in the process of English teaching in colleges and universities, students need to take CET-4 and CET-6, while students only ${ }^{[3]}$ pay attention to the way of written English practice, which hinders the cultivation of students' comprehensive quality $^{[5]}$. For example, a college English test for foreign teachers inside the school found that the grammar score of foreign teachers is lower than that of their own students. Therefore, college English ${ }^{[2]}$ teachers only pay attention to the written teaching content of English, and lack of attention to the scope of application of English practice, ${ }^{[2]}$ so it is difficult to improve the comprehensive ability of the students effectively.

\subsection{The Practicality of English Teaching Theory in Colleges And Universities Needs To Be Im- proved}

In the course $\mathrm{e}^{[1]}$ of the college English teaching in our 
country, the traditional English teaching mode is relatively fixed and cannot be changed according to the development of the society, which makes the English teaching mode of the higher and higher schools to be stagnant. In the course of applying the traditional teaching mode of college English, the teaching mode is too rigid, the teaching meth$\mathrm{od}^{[3]}$ is old, it can't meet the development of the modern society and the actual demand of the international communication. Moreover, ${ }^{[8]}$ in the course of college English teaching in our country, the traditional English teaching theory is practical and the operability is to be improved. The main reason is that the theoretical research and practice have a great difference, which has caused the disjunction between the theoretical research and the practical application of the foreign language. The problem leads to the phenomenon of "unable to land" and "inapproachable" in the theoretical study ${ }^{[2]}$ of English in colleges and universities $^{[6]}$. Therefore, at present, the theoretical research ${ }^{[2]}$ of English teaching in colleges and universities in China has entered the stage of misunderstanding in the attic in the air, and the lack of excellent professionals in the process $^{[2]}$ of English teaching in colleges and universities in China hinders the further development of English teaching in colleges and universities.

\subsection{Not Paying Attention to the Cultivation of Students' English Communicative Competence}

In the process of English teaching in ${ }^{[7]}$ colleges and universities, teachers should pay attention to the improvement of students' comprehensive English ability, and communicative competence is an important symbol of the improvement of English comprehensive ability. Many teachers focus on the process of written knowledge and written expression, and college students generally need to take CET-4 and CET-6 exams, which makes students pay more attention to written practice, but lacks attention to English language communication and communication ability. In order to test CET-4 and CET-6, we only pay attention to the teaching of grammar, vocabulary and other examination skills, which cannot effectively improve students' communicative competence in English language. In addition, in the new media environment, many teachers have introduced multi-media Physical teaching strengthens the ${ }^{[1]}$ communication and communication ${ }^{[1]}$ between teachers and students and between students and students, and provides certain conditions for the communication between students and international friends. However, many college English teachers can not realize the importance of communicative competence in the future development of students, ${ }^{[3]}$ it is difficult to regard it as the key content of English classroom teaching ${ }^{[7]}$ in colleges and universities, and cannot effectively cultivate students' English communicative competence. The effectiveness of ${ }^{[2]}$ English teaching in colleges and universities has been greatly affected.

\section{Optimization measures of English Teach- ing Reform and Innovation ${ }^{[4]}$ in Colleges and Universities under the Environment of New Media}

\subsection{Introduction of New Media Technology And Extension $^{[3]}$ of Teaching Content}

In the process of English teaching reform and innovation in colleges and universities, teachers should take optimizing and extending the teaching content as the key content of practical teaching, constantly optimizing and perfecting the resources in the teaching process, and thus effective$1 y^{[3]}$ improving the overall quality of the cultivation of English majors ${ }^{[4]}$ in colleges and universities. In the new media environment, university teachers should collect a large number of contents related to textbook content ${ }^{[3]}$ with the help of new media technology, and extend the content of English teaching. Therefore, ${ }^{[6]}$ in the teaching process of English majors in colleges and universities, teachers should do the following work well: first, teachers can make use of the search function in Internet technology, and according to the actual requirements and contents of teaching materials, search and teaching materials. Guan's materials, such as English movies, cartoons, English songs, TV dramas, pictures, words and other contents related to teaching materials, can increase the capacity of classroom information, stimulate students' enthusiasm for learning, and then create a good English classroom environment, improve students' comprehensive learning ability, and achieve the effectiveness of English ${ }^{[1]}$ teaching in colleges and universities. Second, at this stage, many ${ }^{[1]}$ colleges and universities in our country have established a perfect database, such as excellent English masterpieces, high-quality English academic papers and so on. Teachers can integrate them with the contents of teaching materials, implement required bibliographies, must-read articles, extend the teaching content in teaching materials, and give full play to their own fingers. Guidance, help students search and read independently, expand students' vision, and then improve students' information processing ability, reading and understanding ability.

\subsection{Sharing of Teaching Resources}

In the process of English teaching in colleges and universities ${ }^{[6]}$, teachers can apply English new media platform, index, classify, screen and screen related network 
resources, integrate ${ }^{[1]}$ a large number of information and resources in the Internet, establish English teaching index platform and unified interface, realize cross-database retrieval, and provide support for search, recommendation, display and consultation in English teaching. At the same time, teachers can communicate and communicate with ${ }^{[1]}$ colleges and universities in many countries in the new media platform ${ }^{[1]}$ to realize the sharing of English teaching resources, so that they can not only browse current events in English news websites, but also read relevant academic magazines and watch foreign English on the Internet. Teaching video, the application of new media platform to strengthen the contact with English teachers and learners from all over the world ${ }^{[7]}$. In addition, the new media has the characteristics of community, interaction, individualization, real-time and diversity, which can provide more abundant information and resources for college English teaching, stimulate students' enthusiasm for learning, broaden students' cultural vision, and then establish a perfect ${ }^{[2]}$ situation of English learning in colleges and universities to improve the effectiveness of English teaching in colleges and universities.

\section{Conclusion}

To sum up, in the development of the new period, the relationship between various countries in the world is getting closer and closer, and all walks of life pay more attention to English teaching. ${ }^{[6]}$ However, in the process of English teaching in colleges and universities, ${ }^{[2]}$ many teachers still implement the traditional teaching model and cannot achieve the expected teaching effect ${ }^{[8]}$. In order to improve this situation, teachers should increase the application of new media platform and information technology, improve the problem that teachers pay too much attention to the content of teaching materials, lack of practical application, and increase the reform and innovation ${ }^{[5]}$ of English teaching in colleges and universities, so as to improve students' comprehensive ability and provide a guarantee for the effectiveness of English teaching.

\section{References}

[1] Dai Min. The Reform and Innovation of English Teaching in Colleges and Universities under the New Media Environment[J]. Out-of-school education in China, 2017(12):95-96.

[2] Liu Xianghui. A preliminary study on the Reform and Innovation of English Teaching in Colleges and Universities under the New Media Environment[J]. Journal of Jiamusi Vocational College, 2018(3):407.

[3] Cao Yuxia. College English Development Teaching: a Review of the Development of College English Teaching in the New Media Environment[J]. Development and Evaluation of higher Education, 2017(03):134.

[4] Nie Xiaoxue. An Analysis of English Teaching Reform and Innovation in Colleges and Universities under the New Media Environment[J]. Science and Education Exchange (mid-issue), 2018443(12):175176.

[5] Tian Chunxia. On the Innovation Reform of College English Teaching from the Perspective of New Media[J]. English Square, 2018, No. 089(05):80-81.

[6] Zhang Fang. College English Teaching in the New Media Environment-A Review of the Development of College English Teaching in the New Media Environment $[\mathrm{J}]$. Development and Evaluation of higher Education, 2017(2).

[7] Shi Shujing. An Analysis of English Teaching Reform and Innovation in Colleges and Universities under the New Media Environment[J]. Journal of higher Education, 2018, No. 83(11):28-30.

[8] Liu Yumeng, Zhang Yinyou. Research on College English Teaching Innovation in the Background of New Network Media[J]. Intelligent, 2018(34):114+116. 